\title{
Patterns and determinants of contraceptives utilization in a religiously homogeneous settlement: a Nigerian Case Study
}

\author{
Ene J.C. ${ }^{1},{ }^{*}$ Adewoyin Y., ${ }^{2,3}$, Chukwu N.A. ${ }^{1}$
}

\begin{abstract}
Objective: To identify the determinants of contraceptive utilization in a religiously homogenous settlement in Nigeria.

Methods: Using Nsukka, Enugu State as a case study, the study utilized primary data generated using a structured questionnaire administered on 600 female respondents aged 15-49 on pre/post-natal care hospital visits. The datasets were analyzed at univariate and bivariate levels and using binary regression.
\end{abstract}

Results: Women aged $20-29$ constituted $44.6 \%$ of the respondents, $80 \%$ were married, $80.2 \%$ were Christians, $42.1 \%$ had secondary education, $5.2 \%$ earned above $\mathrm{N} 80,000$ monthly and $56.8 \%$ used contraceptives. Variations in contraceptive use were found to be significantly associated with age, income, occupation and religion $(\mathrm{P}<0.05)$ while the regression analyses showed that religion was the only significant predictor of contraceptive use among the sample $(\mathrm{P}<0.05)$. Being unemployed became significant only when religion was controlled for.

Conclusion: With religion being a more dominant determinant of contraceptive utilization, even in a largely religiously-homogeneous settlement, scaling up contraceptive usage for population health and development should involve health professionals and social workers in their various churches.

Key words: Contraceptive Use, Religion, Health Professionals, Social Workers, Nsukka, Nigeria

\author{
*Corresponding Author \\ Adewoyin Y. \\ http://orcid.org/0000-0002-9013-4867 \\ Email:yemiadewoyin@yahoo.com \\ ${ }^{1}$ Department of Social Work, University of Nigeria, Nsukka, Nigeria
${ }^{2}$ Department of Geography, University of Nigeria, Nsukka, Nigeria
${ }^{3}$ Schools of Public Health and Social Sciences, University of the Witwatersrand, South Africa
}




\title{
Profils et déterminants de l'utilisation des contraceptifs dans un établissement homogène sur le plan religieux: une étude de cas nigériane
}

\author{
Ene J.C. ${ }^{1}$, *Adewoyin Y., ${ }^{2,3}$, Chukwu N.A. ${ }^{1}$
}

\begin{abstract}
Abstrait
Objectif: Identifier les déterminants de l'utilisation de la contraception dans un établissement homogène sur le plan religieux au Nigéria.

Méthodes: En utilisant l'étude de cas de Nsukka, État d'Enugu, l'étude a utilisé des données primaires générées à l'aide d'un questionnaire structuré administré à 600 femmes de 15 à 49 ans interrogées lors de visites à l'hôpital pour soins pré / postnatals. Les jeux de données ont été analysés aux niveaux univarié et bivarié et à l'aide d'une régression binaire.
\end{abstract}

Résultats: Les femmes âgées de 20 à 29 ans constituaient 44,6\% des répondants, $80 \%$ étaient mariées, $80,2 \%$ étaient chrétiennes, $42,1 \%$ avaient fait des études secondaires, $5,2 \%$ avaient un revenu supérieur à 80000 nuls par mois et $56,8 \%$ utilisaient des contraceptifs. Les variations d'utilisation de la contraception étaient associées de manière significative à l'âge, au revenu, à la profession et à la religion $(\mathrm{P}<0,05)$, tandis que les analyses de régression montraient que la religion était le seul facteur prédictif significatif de l'utilisation de la contraception dans l'échantillon $(\mathrm{P}<0,05)$. Le chômage est devenu significatif seulement lorsque la religion était contrôlée.

Conclusion: la religion étant un facteur déterminant plus important de l'utilisation de la contraception, même dans un établissement largement homogène sur le plan religieux, l'utilisation accrue de la contraception pour la santé et le développement de la population devrait impliquer les professionnels de la santé et les travailleurs sociaux dans leurs différentes églises.

Mots-clés: Utilisation de contraceptifs, Religion, Professionnels de la santé, Travailleurs sociaux, Nsukka, Nigéria

\footnotetext{
*Auteur principal

Adewoyin Y.

http://orcid.org/0000-0002-9013-4867

Email:yemiadewoyin@yahoo.com
}

${ }^{1}$ Department of Social Work, University of Nigeria, Nsukka, Nigeria

${ }^{2}$ Department of Geography, University of Nigeria, Nsukka, Nigeria

${ }^{3}$ Schools of Public Health and Social Sciences, University of the Witwatersrand, South Africa 


\section{INTRODUCTION}

Population growth comes with its merits and demerits. When not properly harnessed, the demerits usually outweigh the merits. In most developing countries, harnessing the demographic dividends has become a growing concern largely because the rate of population growth far outstrips and puts pressure on existing social and physical infrastructure available to support the population. The rapid growth rate in these countries, Nigeria inclusive, is attributed to high fertility, increased birth rate and low contraceptive utilization [1]. Studies have shown that while contraceptives utilization has increased across the globe, it has remained very low in sub-Saharan Africa [2-4]. Global contraceptives utilization is over $50 \%$ while it is substantially less than $25 \%$ in Africa $[5,6]$. In Nigeria, the National Demographic and Health Survey (NDHS) of 2013 reported a contraceptive utilization rate of about 15\% [7]. The uptake was $13 \%$ ten years earlier [8]. In the highlights of the 2018 NDHS, the uptake has only risen marginally to $17 \%$ [9].

Several scholars have investigated the divergent reasons why contraceptive utilization is low in developing countries [10-16]. These studies found that finance, knowledge, availability, awareness, literacy level, religion and so on, are the main determinants of contraceptives utilization. Most of these studies however did not emphasize the influence of local contextual factors on the determinants of contraceptive utilization. In Nigeria for example, there are certain attributes that are geographic and peculiar to places. These include high level of literacy in the South-West, higher female enrolment in the South-East, religious homogeneity in most Northern and South-East States etc. These attributes have implications for the uptake of contraceptives and will vary in magnitude as determinants of contraceptive utilization among places in Nigeria [17-21]. It follows therefore that policies to address population growth through the utilization of contraceptives must take the geographical attributes of places into cognizance to achieve the desired results.

This study is therefore an endeavor at identifying the local determinants of contraceptives utilization in Nsukka, Nigeria. Nsukka becomes particularly important as a case study for many reasons. There are several public and mission-owned health facilities operating at a highly subsidized rate in Nsukka, hence accessibility and affordability may not be major determinants in this locality. It is also, largely, a culturally homogeneous city with Christianity as the dominant religion. The Christian faith, particularly the Catholic denomination which is the most prevalent in the city, is renowned for its stance towards abortion and contraceptives utilization. This may also have implications for utilization in the locality. It is against this background that this study is posing the research question of what the major determinants of contraceptive utilization in a predominantly religious and culturally homogenous locality like Nsukka are.

\section{METHODS}

The study adopted a cross sectional survey research design using primary data. The area selected for the study was Nsukka, Enugu State, Nigeria. Nsukka is a semi-urban settlement with a major urban center and 18 rural localities. The estimated population of Nsukka is 309,633 comprising of 149,241 males and 160,392 females [22]. The inhabitants are predominantly Christians with majority being of the Catholic denomination. The population for the study consists of child-bearing women in Nsukka within the ages of 15 and 49 years. The population of child-bearing women in Nsukka town was projected to be 88,458 in 2016 by the Nsukka Town Planning Authority. Of these, and using following Yamane [23], a sample size of 600 respondents was drawn for the study. The sample consisted of child-bearing women who visited the government or mission health facilities for their pre/post-natal services.

The study employed a multi-stage sampling technique in selecting the respondents. The first stage involved a grouping of the hospitals in Nsukka and its rural localities based on ownership; government or private. Private hospitals were further decomposed into those owned by religious organizations (mission hospitals) or private individuals. The hospitals were further categorized based on locality; Nsukka Urban and Rural Nsukka. Three government hospitals and three mission hospitals were thereafter randomly selected in the categories through balloting. Thus, in Nsukka urban, one government and one mission hospital were selected while in the rural localities of the study area, two government and two mission health facilities were selected. The choice of both the government and mission hospitals was predicated on the subsidized costs of healthcare in both hospital categories as against the high cost in private hospitals. Private hospitals in Nigeria, 
as elsewhere, are run for profit and are more expensive than government and mission hospitals. Further, maternal treatment in government hospitals are free and subsidized in Nigeria while in the mission hospitals, concessions are given to patients of the same religious denomination as the facility owners. Using equal representation among the hospitals, a total of 100 respondents were drawn from each facility.

Data collection for the study was through a structured questionnaire divided into two sections. Section A focused on the respondents' demographic data while section B focused on contraception and its uptake. The questionnaire was administered by the authors and four research assistants. A total of 572 copies of the questionnaire were however valid for data analysis. Study data were analyzed using frequency tables and percentages, Chi Square test and Binary Logistic Regression analysis. In the regression model, contraceptive utilization, coded in the binary form of Yes or No, was the dependent variable while place of residence, age o f r e s p o n d e n t s, re 1 i g i o u s affiliation/denomination, education, occupation, number of children and income were the independent variables. To further determine the relationship between the predictors and contraceptive utilization within the context of religion in the study area, a second regression model was run while adjusting for religion.

\section{Ethical Considerations}

The study was non-invasive and social scientific. The Management of the facilities used approved the researchers' interactions with the respondents. All respondents were informed of the purpose of the study and informed consent was obtained from those who indicated interest before the questionnaire was administered on them.

\section{RESULTS}

\section{Descriptive Analysis}

Of the 572 respondents, $80.2 \%$ were Christians of various denomination while those aged 20-39 constituted $67 \%$ of the sample. Married respondents were almost 80\%, 84.4\% had at least primary education and $31.5 \%$ were either unemployed or students. Most of the respondents $(53.5 \%)$ were traders and artisans and the income range of N41,000 - N60,000 per month was more predominant (31.6\%) among the sample. More than $45 \%$ of the sample had between 4 and 6 children while $3.3 \%$ had more than 10 children (Table 1). Nearly $57 \%$ of the respondents used contraceptives with government health facilities as the preferred place of uptake. The commonest form of contraception used was the withdrawal/calendar charting method $(27.2 \%)$ while male/female condom constituted the highest form of modern contraceptive method used (9.8\%). About 24\% have used contraceptives for not more than 3 years. Church groups were least responsible for the respondents' decision to use contraceptives $(3.3 \%)$ and also constituted the least source of contraceptive information to the respondents $(0.7 \%)$. Religion $(24.2 \%)$ was the most cited reason for non-use and menstruation related effects $(67.5 \%)$ were the most prevalent side effects noted by the respondents (Table 2 ).

\section{Pattern of Contraceptive Use and Multivariate Analyses}

The proportion of contraceptive users was much higher among urban dwellers (83.1\%) than rural dwellers in the sample. Respondents aged 20-29 (48.6\%), who were married (80.3\%) and who had at least secondary education (49.8\%) used contraceptives more. Quite interestingly, majority of those who used contraceptives were Catholics (44.3\%). They also constituted the bulk of those who did not use $(34.4 \%)$. Non-use of contraceptives was highest $(32.4 \%)$ among respondents who earned not more than N20,000 in a month and those who have had between 4 and 6 children (47.4\%). Place of residence, whether rural or urban, marital status, educational attainment and number of children were however not statistically significant in their association with contraceptive use in the study area (Table 3).

In the first regression model that included all the predictors, including religion, being resident in a rural area, levels of education and earning above N60,000 in a month had less likelihood of not using contraceptives while the other variable categories increased the likelihood of not using contraceptives. In the model, only religion was statistically significant. From the results, being a Muslim, a Catholic or an Anglican significantly increased the odds of not using contraceptives. When the model was adjusted to control for religion, the pattern remained almost the same except that being unemployed became statistically significant in increasing the odds of not using contraceptives (Table 4). 


\section{DISCUSSION}

With $56.8 \%$ of the sample using contraceptives, Nsukka presents a profile that suggests that it is a settlement with a high prevalence of contraceptive use. When the usage pattern is disaggregated however, the proportion using modern contraceptives is $25.6 \%$ of the total sample. While this figure is much higher than the national average of $17 \%$, it still shows a low level of contraceptive uptake that typifies many African countries and settlements [2-6]. The decision to use contraceptives among the respondents was mainly from the women, followed by family and friends, and then husbands. This suggests that the level of awareness of the benefits of using contraception is high among the respondents. This may necessarily be so as more than $84 \%$ of the sample had at least primary education and less than $2 \%$ attributed their non-use of contraceptives to lack of awareness. Previous studies have shown that husbands' approval and education are critical in the decision to use contraceptives [21, 24]. Religion was the most singular reason for not using contraceptives in the study area while the Church was least responsible for contraception information and the women's decision to use contraceptives. This finding aligns with previous studies that have shown that religion matters for increasing contraceptive uptake in Nigeria [19, $25,26]$.

This study also shows that contraceptive utilization varies with place of residence, age, marital status, level of education, religion, income, occupation, and number of children as shown in various studies on subject [10-20]. Unlike in most of these studies however, the results of the bivariate associations show that the variations are only statistically significant with age, religion, income and occupation in this study. Respondents aged 40-49, Catholics, earning over N80,000 a month and skilled professionals not in civil or public employment recorded the lowest proportions of nonutilization in the study sample. The finding on income, particularly, contradicts the generally established pattern on the association between income and contraceptive use that the prevalence of contraception is lowest among poorer populations. The result may not be unconnected with the fact that respondents in this income category were only $5.2 \%$ of the sample.

The results of the regression analyses further confirm that the associations were not sufficient enough to predict contraceptive utilization in the study area as religion was the only significant predictor in Model 1. Religion has been shown to substantially predict contraceptive utilization in Northern Nigeria [19, $25,26]$. To underscore the importance of religion, Ayong suggested that religion be given a primary role in the government's efforts to control family size in Nigeria [25]. When religion was controlled for, being unemployed was the only significant predictor of utilization in the second model. Occupational status was also found to influence contraceptive utilization [26] These findings imply that even in a predominantly Christian settlement, religion, and particularly religious denomination, impacts contraceptive use.

\section{CONCLUSION}

Nsukka is a predominantly Christian settlement with pockets of other religious adherents dwelling largely in its rural communities as migrant settlers and traders. With more than $80 \%$ of the sample being Christians, the study showed that contraceptive utilization in this largely religiously homogenous settlement is higher than the national average and is less influenced by the known sociodemographic determinants established in the literature. Rather, religion, with its denominational components, was found to be the most significant predictor of contraceptive use in the study area. As religion and the churches constituted the least source of information on contraceptive use in the study area, efforts at increasing contraceptive awareness and uptake, and by extension, its benefits and implications for population health and national development, should be scaled up through the religious institutions. A way of achieving this is through periodic professional talks during health weeks in the churches and at church group meetings by members of the church who are health professionals and social workers.

Acknowledgement: The authors acknowledge the support of the Management of all the major health facilities in Nsukka for their cooperation during the data collection process.

\section{REFERENCES}

1. Population Reference Bureau. World Population Data Sheet with a special focus onWomen Empowerment. 2015; retrieved from www.prb.org/pdf15/2015-world-populationdata-sheet-eng

2. Darroch JE, Sadgh G, Ball H. Contraceptives Technologies: Responding to Women's Need. New York, Guttmacher Institute, 2011.

3. Adebowale SA, Palamuleni M. Determinants of 
Unmet Need for Modern Contraception and Reasons for Non-Use among Married Women in Rural Areas of Burkina Faso. African Population Studies, 2014; 28: 499-514.

4. Kena AM, TagurumYO, Hazan Z, et al. Prevalence and Determinants of Contraceptive use in Rural North East Nigeria: Result of a Qualitative and Quantitative Assessment. Annals of Nigeria Medicine, 2016; 10(1): 3-10.

5. United Nations (UN). World Contraceptive Use Data Sheet 2011. New York.

6. World Health Organization(WHO).World Health Statistics 2014. Retrieved from http://apps.who int/iris/bitstream/10665/112738/119789240692 61-eng.pdf

7. National Population Commission (NPC) [Nigeria] and ICF International (2014). Nigeria Demographic and Health Survey 2013. Abuja, Nigeria, and Rockville, Maryland, USA: NPC and ICF International

8. National Population Commission (NPC) [Nigeria] and ICF Macro (2009). Nigeria Demographic and Health Survey 2008. National Population Commission and ICF Macro, Abuja, Nigeria

9. National Population Commission (NPC) [Nigeria] and ICF. (2019). Nigeria Demographic and Health Survey 2018 Key Indicators Report. Abuja, Nigeria, and Rockville, Maryland, USA: NPC and ICF

10. Assefa H, Firkewold H. Factors Affecting Unmet need for Family Planning in Southern-Nation, Nationalities and Peoples Region, Ethiopia. Ethiopian Journal of Health and Science, 2011; 21(2): 77- 89

11. Nonvigon J, Nonvigon J. Trends and Determinants of Contraceptive Uses among Women Reproductive Age in Ghana. African Population Studies, 2014; 28(2): 23-31

12. Mojok E, Smesny A, Ekabua J, Essien JE. Contraceptive Practice in Nigeria: Literature Review and Recommendations for Future Policy Decisions. Open Access Journal of Contraception, 2010. Accessed from DOI:10.2147/OAJCS9281

13. Olowande TI, Fasasi LT. Family Planning Perception and Sustainable Development in Nigeria (2017). Covenant International Journal of Psychology (CIJP), 2017; 2: 45-51

14. Fayehun F. Contraceptive Use in Nigeria is Incredibly Low. A Lack of Knowledge maybe Why. The Conversation Africa, 2017. Retrieved from the conversation.com $>$ contraceptives

15. Solanke BL. Factors Influencing Contraceptive use and non-use among Women of Advanced Reproductive Age in Nigeria. Journal of Health Population and Nutrition, 2017; 36(1): 36-42 Retrieved from doi:10.1186/s41043-016-0077-6

16. Ndayizigiye L, Fawzi C, Lively O, Ware I. Understanding low Uptake of Contraceptive in Resource Limited Setting: A Mixed Method Study in Rural Burundi. BMC Health Service Research, Bio-Med Central 2017. Doi: 10.1186/s12913-017-21444-0

17. Ejembi C, Dahiru T, Aliyu A. Contextual Factors influencing Modern Contraceptive Use in Nigeria. Demographic Health Survey Working Papers No 120, 2015. Rockville, Maryland, USA, ICF International.

18. Blackstone S, Iwelunma J. Determinants of Contraceptive Use among Nigerian Couples: Evidence from 2013 Demographic Health Survey (DHS). Contraception and Reproductive Medicine Journal, 2017; 34: 17-37

19. Babalola S, Oyenubi O. Factors Explaining the North-South Differentials in Contraceptives use in Nigeria: A Nonlinear Decomposition Analysis. Demographic Research, 2018; 38(12): 287-308.

20. Odimegwu CO. Family Planning Attitudes and Use in Nigeria: A Factor Analysis. International Family Planning Perspectives, 1999; 25(2): 8691

21. Onwuzurike, B.K. and Uzochukwu, B.S.C. (2001). Knowledge, Attitude and Practice of Family Planning amongst Women in a HighDensity Low-Income Urban of Enugu, Nigeria African Journal of Reproductive Health, Vol. 5, No. 2, pp. 83-89

22. National Bureau of Statistics, Nigeria. Central Data Catalog. National Data Archives, Nigeria, 2010.

23. Yamene T. Statistics: An introductory Analysis. New York, Harper and Row pub, 1967.

24. Izugbara $\mathrm{CO}$ and Ezeh, AC. Women and High Fertility in Islamic Northern Nigeria. Studies in Family Planning, 2010; 41(3): 193-204

25. Avong HN. Perception of and Attitudes toward the Nigerian Federal Population Policy, Family Planning Program and Family Planning in Kaduna State, Nigeria. African Journal of Reproductive Health, 2000; 4(1): 66-76

26. Unumeri G, Ishaku S, Ahonsi B and Oginni A. Contraceptive Use and Its Socio-economic Determinants among Women in North-East and North-West Regions of Nigeria: A Comparative Analysis. African Population Studies, 2015; 29(2): 1851-1867 
Table 1: Sociodemographic characteristics of respondents

\begin{tabular}{|c|c|c|}
\hline Characteristics & Frequency & Percentage (\%) \\
\hline \multicolumn{3}{|l|}{ Age } \\
\hline $15-19$ & 146 & 25.5 \\
\hline $20-29$ & 256 & 44.8 \\
\hline $30-39$ & 127 & 22.2 \\
\hline $40-49$ & 43 & 7.5 \\
\hline \multicolumn{3}{|l|}{ Marital status } \\
\hline Single & 66 & 11.5 \\
\hline Married & 457 & 79.9 \\
\hline Separated & 33 & 5.8 \\
\hline Widowed & 12 & 3.1 \\
\hline Divorced & 4 & 0.7 \\
\hline \multicolumn{3}{|l|}{ Religious affiliation } \\
\hline Catholic & 229 & 40.0 \\
\hline Anglican & 113 & 19.7 \\
\hline Pentecostal & 117 & 20.5 \\
\hline Muslim & 60 & 10.5 \\
\hline Traditional & 53 & 9.3 \\
\hline \multicolumn{3}{|c|}{ Highest education obtained } \\
\hline No formal education & 89 & 15.6 \\
\hline Primary & 181 & 31.6 \\
\hline Secondary & 241 & 42.1 \\
\hline Tertiary & 61 & 10.7 \\
\hline \multicolumn{3}{|c|}{ Level of income (Naira) } \\
\hline $0-20,000$ & 175 & 30.7 \\
\hline $21,000-40,000$ & 136 & 23.8 \\
\hline $41,000-60,000$ & 181 & 31.6 \\
\hline $61,000-80,000$ & 50 & 8.7 \\
\hline 80,000 and above & 30 & 5.2 \\
\hline \multicolumn{3}{|c|}{ Occupation of respondents } \\
\hline Unemployed & 89 & 15.6 \\
\hline Student & 91 & 15.9 \\
\hline Trader/Unskilled & 209 & 36.5 \\
\hline Skilled/Artisan & 97 & 17.0 \\
\hline Professional & 7 & 1.2 \\
\hline Civil servant & 79 & 13.8 \\
\hline \multicolumn{3}{|c|}{ Previous No of children } \\
\hline $0-3$ & 166 & 29.0 \\
\hline $4-6$ & 261 & 45.6 \\
\hline $7-9$ & 126 & 22.0 \\
\hline 10 and above & 19 & 3.3 \\
\hline
\end{tabular}


Table 2: Dimensions of contraceptive utilization among the respondents

\begin{tabular}{|c|c|c|}
\hline Dimension & Frequency & Percentage $(\%)$ \\
\hline \multicolumn{3}{|l|}{ Use contraceptives } \\
\hline No & 247 & 43.2 \\
\hline Yes & 325 & 56.8 \\
\hline \multicolumn{3}{|l|}{ Where is it done? } \\
\hline No response & 247 & 43.2 \\
\hline Traditional & 23 & 4.0 \\
\hline Patent drug sellers & 52 & 9.1 \\
\hline Mission health clinics & 17 & 3.0 \\
\hline Government health clinics & 233 & 40.7 \\
\hline \multicolumn{3}{|l|}{ Type of contraceptive in use } \\
\hline No response & 247 & 43.2 \\
\hline Traditional (padlock/ring) & 23 & 4.0 \\
\hline Natural (calendar charting/withdrawal) & 155 & 27.2 \\
\hline Male condom & 33 & 5.8 \\
\hline Female condom & 23 & 4.0 \\
\hline Diaphragm & 6 & 1.0 \\
\hline Contraception injections & 18 & 3.1 \\
\hline IUCD & 10 & 1.7 \\
\hline Pills & 46 & 8.1 \\
\hline Implants & 4 & 0.7 \\
\hline Vasectomy & 3 & 0.5 \\
\hline Bilateral tubal ligation & 4 & 0.7 \\
\hline \multicolumn{3}{|l|}{ Duration of contraceptive use } \\
\hline No response & 247 & 43.2 \\
\hline $0-3$ years & 135 & 23.6 \\
\hline $4-7$ years & 98 & 17.1 \\
\hline 8years and above & 92 & 16.1 \\
\hline \multicolumn{3}{|l|}{ Decision to use contraception } \\
\hline Husband & 118 & 20.6 \\
\hline Wife & 245 & 42.8 \\
\hline Family/friends & 122 & 21.3 \\
\hline Hospital & 68 & 11.9 \\
\hline Church group & 19 & 3.4 \\
\hline \multicolumn{3}{|l|}{ Reasons for non-use } \\
\hline No response & 325 & 56.8 \\
\hline Side effect & 28 & 4.9 \\
\hline Finance & 57 & 10.0 \\
\hline Religion & 138 & 24.2 \\
\hline Husbands reaction & 14 & 2.4 \\
\hline Lack of awareness & 10 & 1.7 \\
\hline \multicolumn{3}{|l|}{ Perceived side effect } \\
\hline Weight gain & 117 & 20.5 \\
\hline Weight loss & 39 & 6.8 \\
\hline Heavy menses & 192 & 33.6 \\
\hline Irregular menses/Irreversible & 194 & 33.9 \\
\hline Promiscuity/Barrenness & 30 & 5.2 \\
\hline \multicolumn{3}{|l|}{ Source of contraceptive information } \\
\hline Print media & 51 & 8.9 \\
\hline Electronic media & 163 & 28.5 \\
\hline Hospital & 274 & 47.9 \\
\hline Family/friends & 80 & 14.0 \\
\hline Church group & 4 & 0.7 \\
\hline
\end{tabular}


Table 3: Sociodemographic patterns of contraceptive use

\begin{tabular}{|c|c|c|c|}
\hline Variable & F-Value & Non-Use (\%) & Use (\%) \\
\hline Place of Residence & 0.163 & & \\
\hline Rural & & 18.2 & 16.9 \\
\hline Urban & & 81.8 & 83.1 \\
\hline Age & $9.667 *$ & & \\
\hline $15-19$ & & 29.6 & 22.5 \\
\hline $20-29$ & & 39.7 & 48.6 \\
\hline $30-39$ & & 20.6 & 23.4 \\
\hline $40-49$ & & 10.1 & 5.5 \\
\hline Marital status & 7.074 & & \\
\hline Single & & 10.5 & 12.3 \\
\hline Married & & 79.4 & 80.3 \\
\hline Separated & & 6.9 & 4.9 \\
\hline Widowed & & 1.6 & 2.5 \\
\hline Divorced & & 1.6 & - \\
\hline Religious affiliation & $12.687 *$ & & \\
\hline Catholic & & 34.4 & 44.3 \\
\hline Anglican & & 19.0 & 20.3 \\
\hline Pentecostal & & 23.9 & 17.8 \\
\hline Muslim & & 9.7 & 11.1 \\
\hline Traditional & & 13.0 & 6.5 \\
\hline Highest education obtained & 6.321 & & \\
\hline No formal education & & 15.8 & 15.4 \\
\hline Primary & & 27.5 & 34.8 \\
\hline Secondary & & 42.9 & 41.5 \\
\hline Tertiary & & 13.8 & 8.3 \\
\hline Level of income (Naira) & $24.810 * *$ & & \\
\hline $0-20,000$ & & 32.4 & 29.2 \\
\hline $21,000-40,000$ & & 16.2 & 29.5 \\
\hline $41,000-60,000$ & & 31.2 & 32.0 \\
\hline $61,000-80,000$ & & 13.8 & 4.9 \\
\hline 80,000 and above & & 6.5 & 4.3 \\
\hline Occupation of respondents & $19.940 * *$ & & \\
\hline Unemployed & & 12.1 & 18.2 \\
\hline Student & & 19.4 & 13.2 \\
\hline Trader/Unskilled & & 30.4 & 41.2 \\
\hline Skilled/Artisan & & 17.8 & 16.3 \\
\hline Professional & & 1.2 & 1.2 \\
\hline Civil servant & & 19.0 & 9.8 \\
\hline Previous No of children & 1.377 & & \\
\hline $0-3$ & & 26.7 & 30.8 \\
\hline $4-6$ & & 47.4 & 44.6 \\
\hline $7-9$ & & 22.3 & 21.8 \\
\hline 10 and above & & 3.6 & 2.8 \\
\hline
\end{tabular}

* Significant at $\mathrm{P}<0.05$

$* *$ Significant at $\mathrm{P}<0.001$ 
Table 4: Summary of Regression Analyses

\begin{tabular}{|c|c|c|c|c|}
\hline \multirow[t]{2}{*}{ Predictor } & \multicolumn{2}{|l|}{ Model 1} & \multicolumn{2}{|l|}{ Model 2} \\
\hline & Odds Ratio & Standard Error & Odds Ratio & Standard Error \\
\hline \multicolumn{5}{|l|}{ Place of Residence } \\
\hline Rural & 0.888 & 0.24 & 0.903 & 0.24 \\
\hline Urban & $\mathrm{RC}$ & & & \\
\hline \multicolumn{5}{|l|}{ Age } \\
\hline $15-19$ & 1.040 & 0.43 & 0.947 & 0.42 \\
\hline $20-29$ & 1.818 & 0.38 & 1.590 & 0.37 \\
\hline $30-39$ & 1.975 & 0.39 & 1.653 & 0.38 \\
\hline $40-49$ & $\mathrm{RC}$ & & & \\
\hline \multicolumn{5}{|l|}{ Religious affiliation } \\
\hline Catholic & $2.595^{*}$ & 0.33 & & \\
\hline Anglican & $2.036^{*}$ & 0.36 & & \\
\hline Pentecostal & 1.433 & 0.35 & & \\
\hline Muslim & $2.826^{*}$ & 0.41 & & \\
\hline Traditional & $\mathrm{RC}$ & & & \\
\hline \multicolumn{5}{|c|}{ Highest education obtained } \\
\hline No formal education & 0.577 & 0.57 & 0.563 & 0.56 \\
\hline Primary & 0.839 & 0.53 & 0.850 & 0.52 \\
\hline Secondary & 0.814 & 0.50 & 0.820 & 0.49 \\
\hline Tertiary & $\mathrm{RC}$ & & & \\
\hline \multicolumn{5}{|c|}{ Level of income (Naira) } \\
\hline $0-20,000$ & 1.302 & 0.63 & 1.281 & 0.62 \\
\hline $21,000-40,000$ & 2.081 & 0.60 & 2.004 & 0.58 \\
\hline $41,000-60,000$ & 1.232 & 0.57 & 1.163 & 0.56 \\
\hline $61,000-80,000$ & 0.499 & 0.56 & 0.504 & 0.55 \\
\hline 80,000 and above & $\mathrm{RC}$ & & $\mathrm{RC}$ & \\
\hline \multicolumn{5}{|c|}{ Occupation of respondents } \\
\hline Unemployed & 2.595 & 0.52 & $2.847^{*}$ & 0.51 \\
\hline Student & 1.071 & 0.50 & 1.085 & 0.49 \\
\hline Trader/Unskilled & 1.815 & 0.42 & 1.923 & 0.41 \\
\hline Skilled/Artisan & 1.394 & 0.43 & 1.455 & 0.43 \\
\hline Professional & 1.963 & 0.88 & 1.727 & 0.86 \\
\hline Civil servant & $\mathrm{RC}$ & & $\mathrm{RC}$ & \\
\hline \multicolumn{5}{|c|}{ Previous No of children } \\
\hline $0-3$ & 1.821 & 0.54 & 1.615 & 0.54 \\
\hline $4-6$ & 1.275 & 0.53 & 1.156 & 0.52 \\
\hline $7-9$ & 1.441 & 0.54 & 1.320 & 0.54 \\
\hline 10 and above & $\mathrm{RC}$ & & $\mathrm{RC}$ & \\
\hline
\end{tabular}

*Significant at $\mathrm{P}<0.05$

$\mathrm{RC}-$ Reference Category 